\title{
Modeling of the Investment Process in Russian Agriculture
}

\author{
Stanislava KONTSEVAYA, Natalya ZARUK, Maksim GALKIN, Irina \\ MAKUNINA, Alla MIRONTSEVA \\ Russian State Agrarian University - Moscow Timiryazev Agricultural Academy, Moscow, \\ Russian Federation \\ s.kontsevaya@gmail.com, zaruk86@bk.ru, maksongal@mail.ru, \\ makunina_ivelist.ru, mirontseva_a@list.ru
}

\begin{abstract}
This article contains quantitative evaluation of impact of investments in nominal capital on increasing growth rates of agricultural products. Evaluation was made by means of correlation regression analysis. The research includes developed and estimated ARDL-model which describes short term and long term impact of investments on growth rates of agricultural production taking into account reinvestment of some part of gross revenue. An amount of investments needed to provide average annual growth rates at the level of $5 \%$ in Russian agriculture was calculated in the article. Obtained results can be used for generation of development strategy of agriculture.
\end{abstract}

Keywords: Agriculture, Investment, Economic Growth, Autoregressive, Modeling.

\section{$1 \quad$ Introduction}

Different economic schools such as Keynesian and Neokeynesians, Marxist, Neoclassical consider investment to be a critical driver of economic development. When conducting large-scale socio-economic reforms aimed at ensuring sustainable economic growth and improving living standards of the population, a key place is given to encourage investment. Accordingly, the state of the economy or particular industry can be measured by the nature of the processes happening in the investment sphere. Agriculture is a major industry that supports the country's food security. The most important task of the economy is to provide and engage in an agricultural investment of a size necessary to operate with the pace of growth, ensuring food security of Russia, and a steady output of food products for export. Agrarian import ban make a big influence on Russia agriculture [3,4]. In this regard, modeling of investment process in agriculture, with the purpose of establishing a methodological substantiation of calculation of the volume of investments necessary for expanded reproduction on the basis of innovation is relevant.

Economic theory looks at the investment process as part of reproduction, which is subject to the General laws of development. Various economic schools have taken a 
closer look at Issues of investment, accumulation and the efficiency of capital investments.

Among the popular scientific works are from A. Smith, J. Keynes, P. Samuelson, K. McConnell, Brue, W. Sharpe, G. Markowitz ect [1, 6].

Russian economic scientists dealt extensively with issues related to establishing investment activities among whom are Maslova, I. G. Usachev [2, 7].

Market practice raises theoretic questions which compel us to reconsider previously taken stance and wording. Reasons being that at different cycles of economic development functions, methods, and principles of investment manifest themselves in different ways. The investment activity is measured by the change in the long-term assets. [5].

\section{The modern state of investment activity in Russian agriculture}

Currently, the situation in the investment sphere of the Russian Federation can be characterized as extremely negative. 2014 marked a strong negative trend in the dynamics of investment in fixed capital and the economic downturn in the industrial sector. The reason for this is the significant complication of the financial and economic situation caused by the sharp decline in oil prices, which in turn led to a twofold devaluation of the national currency. The European Union also played a significant role by the introduction of sanctions, which blocked access of major

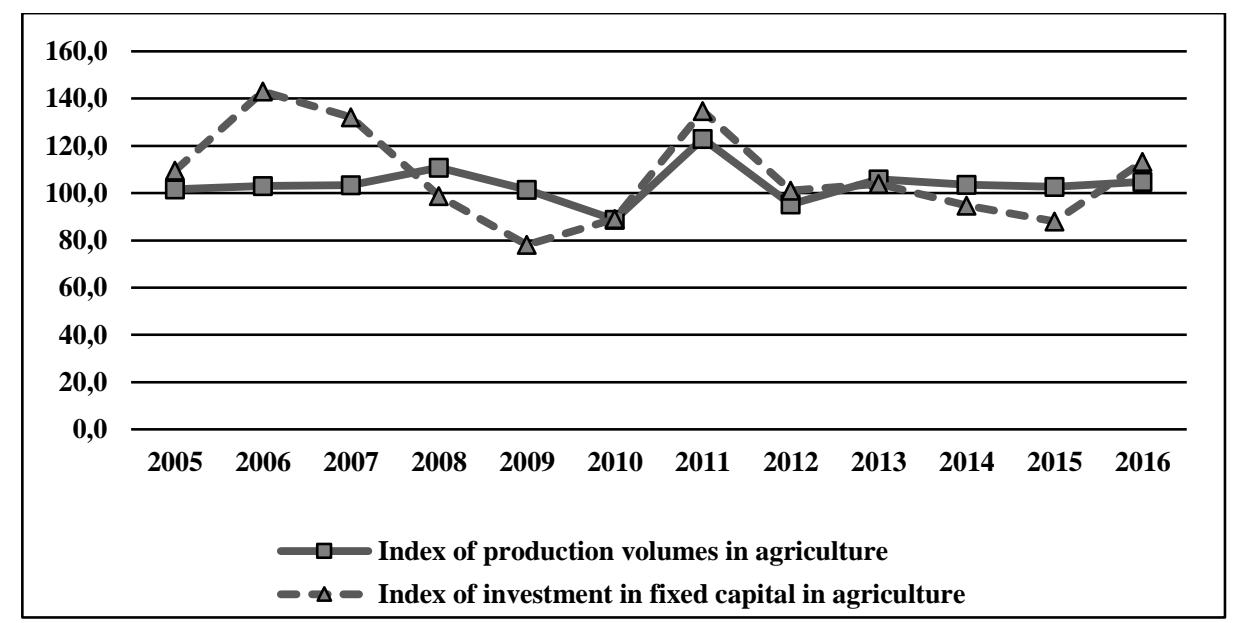

Fig. 1. The indexes of production volumes and investments in fixed capital in the agricultural sector of the Russian Federation from 2005-2016 years (\% to previous year).

Russian banks to cheap foreign credit. The excess return in the foreign exchange market in conditions of high volatility contributed to the flow of capital from the real sector into speculative, which further aggravated the situation in the economy. 
However, despite the negative economic and financial background, the agricultural sector, in contrast, has seen a steady increase in production volumes (Fig. 1).

In 2014-2015, the annual growth rate of production in agriculture were at the level of $3 \%$, in 2016 , this ratio increased to $4.8 \%$, while increasing investment in fixed capital industry by $13.3 \%$ compared to the previous year. Nevertheless, there have been standards of the doctrine of food security for most types of food, as well as the expanded presence of Russian agricultural products in foreign markets. According to the Ministry of agriculture, Russia occupies the leading positions on the world grain market, the export of which in 2016 increased by $10.4 \%$, the volume of exports of beet sugar increased 12.6 times, pork by $4.3 \%$ and poultry by 1.6 times, as well as vegetable oils at $24 \%$. In the period spanning from 2014-2016, the industry had significantly increased the average profitability of production (Fig.2).

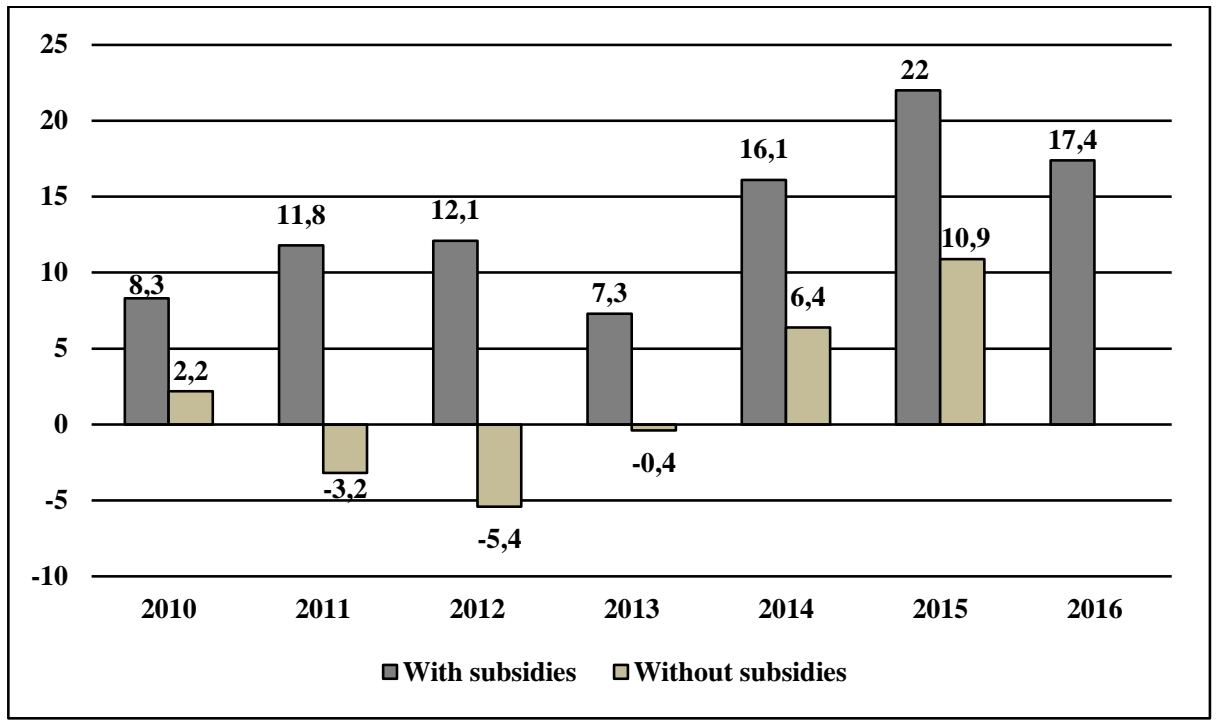

Fig. 2. Dynamics of average profitability of production in agriculture of Russia in 2010-2016 years, \%

In the pre-crisis period, the profitability in agriculture excluding subsidies was characterized by negative values, while in 2014 there was a significant growth of profitability of agricultural producers, and this continued into 2015 . The value of this indicator taking into account subsidies in 2016 fell by almost 5\% to $17.4 \%$ due to falling prices of agricultural producers on domestic and foreign markets with aboveaverage growth costs. Overall, during the crisis, the weakening of the national currency led to the growth in ruble revenues of the agricultural organizations for export activities. Alongside with the action of the food embargo it helped to reduce imports of food. The supply of food and agricultural raw materials from foreign countries, according to Russian Federal State Statistic Service, in the period of 20142016 fell by $38.4 \%$ in value terms from 40 to 25 million US dollar. This was particularly evident, with the dairy products, the volume of import in real terms 
decreased by $17,6 \%$, on meat $-36,2 \%$, vegetables - more than $20 \%$. However, despite these positive trends, the situation in agriculture remains difficult and controversial. There are still problems which have remained unresolved, due to their cross-sectoral macroeconomic in nature. First, there is a strong dependence of the sub-sectors of crop imported seed. The cultivation of sugar beet, sunflower and corn are of immense concern. The share of imported seeds for these crops is about $94 \%$, $50 \%$ and $43 \%$, respectively. It therefore implies that caution should be taken when discussing the last import substitution for these types of crop production. A similar situation is observed in the market of veterinary drugs, vaccines and feed additives. Secondly, the low level of material-technical base and slow introduction of innovative technologies in the industry poses a threat to losing agricultural organizations which ensure conditions for expanded reproduction, and leads to further reinforcement of the technical and technological backwardness of agriculture. The agrarian sector has shown a steady decline of agricultural machinery Park. The number of tractors in during 2014-2016 decreased by $14 \%$ to $223.4 \mathrm{~m} 259$ thousand units, grain harvesters - by $12.67 \%$, milking machines and aggregates of almost $12 \%$. In addition, it was observed that essential improvement was made with the technological characteristics of agricultural machinery that could lead to an increase in performance with a smaller number in agriculture. In line with this, the problem of providing agricultural machines is a priority in the agricultural sector of the economy. Thirdly, there is an urgent need to fix the problem with the development of social infrastructure of rural settlements and improving living standards of agricultural workers. The most important condition for the maintenance of staff stability and development of labor potential of the industry is to ensure an acceptable level of life of workers based on real wage growth. For 2016, the wages in the agricultural sector amounted to about $65 \%$, relative to the average level higher than the previous years. However, about $15 \%$ of people employed in agriculture receive remuneration below the minimum wage. In low-yield agricultural work $17 \%$ of the rural population is below the poverty line. Agricultural development is impossible without creating high-tech jobs; improved labor in agriculture and material incentives.

Consequently, the sustainable development of agriculture is connected with need for the restoration and development of entire sub-sectors of the industry - tractors and agricultural machinery, biological products, development of breeding and seed production base, the development of rural areas. The solution to these problems largely depends on stimulation of investment activity, which to date is not restored in the sector to pre-crisis level in 2013. First and foremost, the development of investment activity in agriculture is constrained by limited access of agricultural producers to preferential short-term and investment lending. Currently, access to cheap credit is enjoyed by a narrow range of agricultural organizations, which are characterized by high profitability, low profit, and especially unprofitable enterprises. In situations where profitable investment projects are available access to Bank lending is almost completely closed.

In order to stimulate investment activity in agriculture it is necessary to increase the availability of credit resources, as well as increased budgetary support, the growth of which should enhance the investment attractiveness of the agricultural sector. In 
accordance it is required to justify the investment resources needed to ensure sustainable economic growth in agriculture. This should produce a quantitative estimate of the impact of investments in basic capital on the growth rate of agricultural production in the retrospective periods, using methods of mathematical modeling and tools of correlation and regression analysis.

\section{Materials and Methods}

The theoretical basis for the specification of the dependence of the indicators of economic growth is from investment to form a model of the accelerator and multiplier. The impact of investment on national income growth is reflected in the multiplier model of investment developed by Jh. Keynes:

$$
\left(I_{t}-I_{t-1}\right)=m \times\left(Y_{t}-Y_{t-1}\right),
$$

where I - investment amount for a specific time interval, $\mathrm{m}$ - the multiplier (shows how many units will change national income by increasing investment in 1 unit), $\mathrm{Y}_{\mathrm{t}}$ is the national income

This model shows that the increase in investment leads to an increase (accumulation) of national income, if the value of the multiplier is greater than 1 .

Also, there is an inverse relationship, which is reflected by the accelerator model of investment suggested by George Clark:

$$
I_{t}=a \times\left(Y_{t}-Y_{t-1}\right),
$$

where $\mathrm{a}-$ the accelerator of investments (showing percentage of national income to be reinvested).

The accelerator model describes the relationship between the increase in national income and investment growth, i.e., shows what proportion of the increase in national income for a certain period turns into investment, in turn generating a multiplier effect.

However, in mathematical modeling of the dependence of agricultural production investment in fixed capital it should take into account that the pace of economic growth has an impact on the investments made not only this year, but in the previous periods, i.e. a time lag between making investments and receiving returns on them. This is due to the long payback period and low rates of capital turnover in agriculture. To reflect the indicated regularities of the investment process allows the autoregressive model with distributed lags (ADL Autoregressive Distributed Lags) formula No. 3 .

$$
y_{t}=b_{0}+b_{1} y_{t-1}+b_{2} x_{t}+b_{3} x_{t-1}+b_{4} x_{t-2},
$$

where $\mathrm{y}_{\mathrm{t}}$ is the gross volume of agricultural production in terms of value, $\mathrm{y}_{\mathrm{t}-1}-\mathrm{y}$ shifted by 1 year, $\mathrm{x}_{\mathrm{t}}$ is investment in fixed capital of the agricultural sector, $\mathrm{x}_{\mathrm{t}-\mathrm{n}}-$ variable $\mathrm{x}$ is shifted by $\mathrm{n}$ years.

The model describes short-term $\left(\mathrm{x}_{\mathrm{t}}-\right.$ for 1 period $)$ and long term $\left(\mathrm{x}_{\mathrm{t}-\mathrm{n}}-\right.$ for two or more periods) the impact of investments in fixed capital of agriculture the growth of 
production volumes, taking into consideration the impact of the reinvestment of a certain percentage of gross income by the variable $\mathrm{y}_{\mathrm{t}-1}$.

Thus, the model autoregressive distributed lag that describe the influence of fixed capital investments on economic growth in the agricultural sector, constructed using the method of generalized moments will be:

$y=0,345 y_{t-1}+6,133 x+0,476 x_{t-1}+2,13 x_{t-2}+2,147 x_{t-3}-1382772(4)$

\section{$4 \quad$ Results and discussion}

Compare actual and calculated values of production volumes in agriculture, obtained using the obtained model, auto regression with distributed lags (Fig. 3).

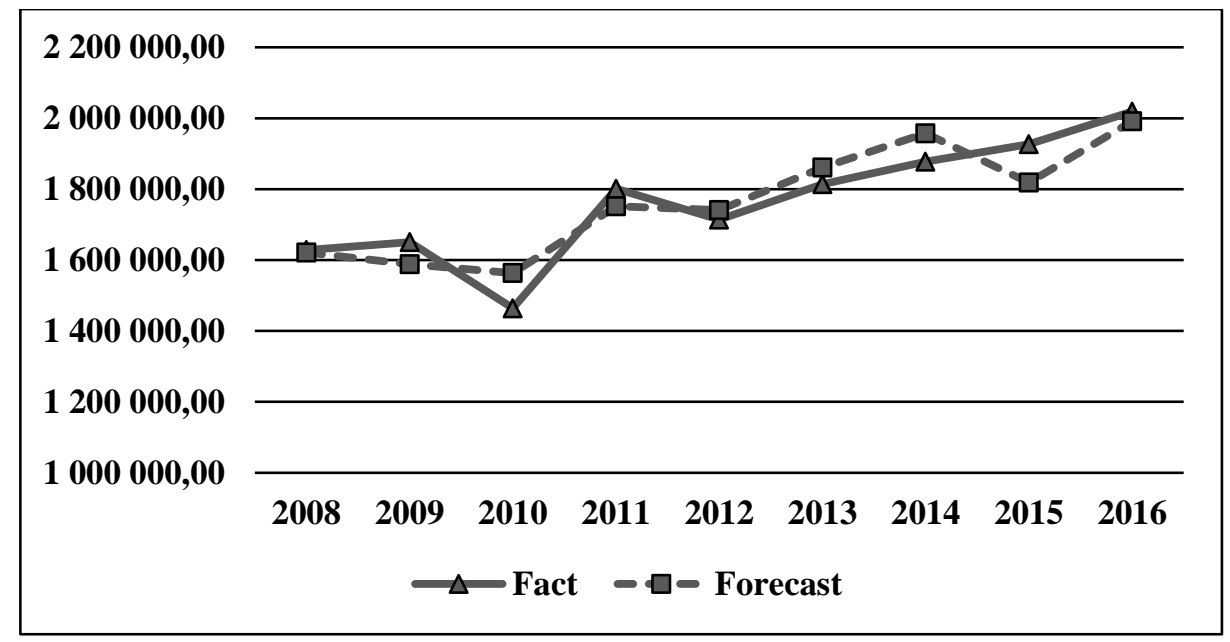

Fig. 3. Actual and calculated values of the volume of agricultural production (in 2005 prices), million rubles

Expected (estimated) value of output of agricultural production is quite close to the actual results. A good approximation of the data is also confirmed by high value of coefficient of multiple determination is 0.83 , respectively; the resulting model can be used in determining the value of capital investment needed for sustainable economic growth in the agricultural sector. With the help of the econometric models the necessary volume of investments (in 2005 prices) are calculated to ensure the average annual growth rates of production volumes in agriculture at 5\% to 2020 (table 1). 
Table 1. Calculation of the necessary volume of investments into the fixed capital of the agricultural sector until 2020

\begin{tabular}{|c|c|c|c|c|c|}
\hline Year & $\begin{array}{l}\text { The volume of } \\
\text { production of } \\
\text { agricultural } \\
\text { products in } \\
2005 \text { prices, } \\
\text { given the } \\
\text { growth rate of } \\
5 \%, \text { million } \\
\text { rubles }\end{array}$ & $\begin{array}{l}\text { Investments in } \\
\text { fixed capital } \\
\text { a/s in } 2005 \\
\text { prices, million } \\
\text { rubles }\end{array}$ & $\begin{array}{l}\text { Investments in } \\
\text { fixed capital in } \\
\text { the prices of } \\
2016, \text { million } \\
\text { rubles }\end{array}$ & $\begin{array}{l}\text { The producer price } \\
\text { index relative to } \\
2016 \text { according to } \\
\text { the forecast of the } \\
\text { RF Ministry of } \\
\text { economic } \\
\text { development, \% }\end{array}$ & $\begin{array}{l}\text { Investments in } \\
\text { fixed capital in } \\
\text { the prices of } \\
\text { the current } \\
\text { year, million } \\
\text { rubles }\end{array}$ \\
\hline 2016 & 2018728.12 & 247169.83 & 611254.40 & 100 & 611254.40 \\
\hline 2017 & 2119664.52 & 275885.70 & 682269.12 & 104.60 & 713653.50 \\
\hline 2018 & 2225647.75 & 285498.61 & 706041.98 & 105.30 & 743462.21 \\
\hline 2019 & 2336930.14 & 276805.18 & 684543.01 & 112.20 & 768057.26 \\
\hline 2020 & 2453776.64 & 276880.79 & 684729.99 & 118.90 & 814143.96 \\
\hline Total & - & - & - & - & 3039316,93 \\
\hline
\end{tabular}

Explaining the procedure for the calculation of presented indicators.

When using the autoregressive model, distributed lag, we determined the necessary volume of investments into fixed capital in 2005 prices. A change of 2.47 was used to bring this indicator to the 2016 prices, which is calculated as the ratio of the volume of investments for the year 2016 at current prices to the same period, expressed in 2005 prices: $611254,40 / 247169,83=2,47$. Furthermore, with the use of producer price indices presented in the forecasts of the Ministry of economic development of the Russian Federation, we determined the volume of investment in the prices of the corresponding period.

Thus, in order to provide average annual growth rates of production volumes in agriculture at the level of 5\% in the period 2017-2020 years it will require more than 3 trillion. RUB of investments in fixed capital of the industry. Assuming a crisis situation, the gradual exit from the crisis, the ratio between private and public investment is 20:80 and 40:60, and the dynamic development of the economy is 70:30.

\section{Conclusion}

Russian agriculture needs investments. The article contains analysis and prediction of agricultural production volumes. ARDL-model was used for this purpose. The model was subjected statistical tests to prove its reliability and high R-square -0.83 .

According to the results of prediction it is needed $3 \mathrm{bln}$. RUB to provide average annual growth rates of 5\% in the period of 2017-2020.

Obviously, without solving the problem of increasing investment activities in a rational balance between market relations and the level of state regulation and support of agriculture, it will be difficult to ensure a sustainable development of the industry, 
the achievement of indicators of import substitution and the expansion of food exports.

\section{References}

1. Gafarova, E.: Modeling the dynamics of the regional investment in fixed capital by regions of the Russian Federation. Socio-economic and technical systems: research, design, optimization (4), 4-8 (2007).

2. Maslova, V.: Lending in the agroindustrial complex: state, problems, solutions. AIC: Economics, management. (9), 28-38 (2017).

3. Smutka, L., Spicka, J., Ishchukova, N., Selby, R.: Agrarian import ban and its impact on the Russian and European Union agrarian trade performance. Agricultural Economics, vol. 62, no. 11, pp. 493-506, (2016) ISSN 1805-9295, DOI 10.17221/294/2015-agricecon

4. Svatos, M., Smutka, L., Ishchukova, N.: The position of agriculture in the Russian Federation - the last two decades development overview. Agricultural Economics, vol. 60, no.11, pp. 489-502, (2014) ISSN 1805-9295.

5. Spicka, J.: Investment Activity of Meat Processing Companies in the Czech Republic. In: Loster, T; Pavelka,The 9th International Days of Statistics and Economics, Prague, Czech Republic, pp. 1570-1580. (2015).

6. Zaruk, N.: Stages of development of investment process in Russian agriculture. Agricultural scientific journal. (1), 69-74 (2016).

7. Zaruk, N., Tagirova, O.: the Role of financial-credit mechanism in terms of import substitution. Niva Povolzhya. 1 (34), 105-113 (2015).

8. Federal State Statistics Service of the Russian Federation, www.gks.ru, last accessed 2017/10/29. 